\title{
Mikhail Gorbachev is back
}

The pre-winter equinox is a time for getting back to serious business. Mr Gorbachev and his counterparts in the West have a great deal to do before they let the northern winter take over.

Mr Mikhail Gorbachev's return from his annual summer vacation is fast becoming an annual global catharsis. When he is away, Moscow is filled with dark rumours and the mutterings now allowed by glasnost, while the rest of the world acts as if it has been unsettled. Then he comes back. Sometimes (as two years ago), he announces that he has written a book. On other occasions, as last week, he contrives confidently to sound as if insoluble problems are also the only problems with which it is worth bothering. Russia would not be the driving force in the Soviet Union if there were not an infinity of insoluble problems, but some, even so, are conspicuous.

There is, for example, what is called the ethnic problem, about which Gorbachev would appear to his predecessors (and does to his contemporary conservative opponents) to be curiously indifferent. Hungary plans to follow Poland, in the autumn, with a kind of free election, the three Baltic states behave as if they wish they could be up in arms, there is discontent throughout the southern republics and Moldavia would reunite with Romania if only that were congenial, but meanwhile demands the right to speak Romanian. The difficulty, for the Soviet republics, is that there are too many of them to cut much ice. Their friends elsewhere are mostly remittance men. In due course, it may be different, but many other things will by then have changed the world.

Second, there is the problem of the Soviet economy, which is bankrupt. The Soviet people cannot feed, or clothe or adequately house themselves. Gorbachev has railed against Stalin as energetically as anybody in his position could, but he has not yet spelled out what needs most simply to be said: that Stalin's exercise of his unchallenged right to squander half a century's investment of the Soviet people's enthusiasm on misguided enterprises is a more serious offence than his better-documented misdemeanours. Yet that is where the truth lies. Nobody asks that the Soviet people should repudiate the past half century, or even pretend that it never happened, but merely that Gorbachev, back from his vacation, should refer to the difficulty from time to time, by way of explanation of why that old enthusiasm has mostly been nugatory.

Third, there is the ideological problem. Gorbachev's licence as president of the Soviet Union is that of a leninist - the right to run a government on marxist lines. If the rules were different, he might have to apply for another licence; nobody can be sure what the outcome of that would be. The unspoken question at Gorbachev's return from his summer vacation is that the unspoken disloyal ideological question may now be unavoidable. If that were indeed the case, of course, everything would change. Gorbachev would probably retire, or take a post as president of a prosperous university in the West. It would be convenient for us all if that issue could be postponed for another year.

So what happens, or should happen, as the long winter closes in on the Soviet Union? First, there needs to be a recognition in the West that, of all the crises in the world, that in the Soviet Union should command the most attention. It is, after all, the most important potential crisis. If, this winter, there should be famine in the Ural district or somewhere else, there will be another Western-looking Dostoevsky, or perhaps several, on the West's back for the rest of time. Second, the outside world (not necessarily coextensive with the West) needs some kind of emergency plan. Third, quite soon, the US administration needs to settle on a plan for arms-control; Washington professes to be preoccupied with schemes for winning advantages from the present hiatus: why does it not offer a test-ban treaty (virtually completed nine years ago) as a gambit, knowing that there can hardly be a more secure agreement?

\section{No news is bad news}

Impatience and intemperance may have persuaded the British government to cancel a timely project.

SoueAmishness is not one of the qualities on which the British government of the past decade prides itself. On the contrary, the government boasts (and even boasts about) qualities at the other end of the spectrum, toughmindedness for example. Yet Mrs Margaret Thatcher, the prime minister, has now used her considerable influence to stifle at birth a research programme meant to help understand the mechanism of the spread of AIDS in Britain. The objective is a social survey of contemporary adult behaviour, sexual behaviour included. The prime minister's office says that she considers that the study would have been "too intrusive" to be supported with public funds. Thatcher may be embarrassed to think of 